\title{
PENGAMBILAN KEPUTUSAN BERDASARKAN FORM API (ANALYSIS PRODUCT INSPECTION)
}

\author{
Mochammaad Muchid', Krisnadhi Hariyanto ${ }^{2}$, Wawan Setia Budi ${ }^{3}$ \\ ${ }^{1,2}$ Universitas Wijaya Putra, Fakultas Teknik \\ ${ }^{3}$ Universitas Wijaya Putra Fakultas Ilmu Hukum \\ muchid@uwp.ac.id, krisnadi@uwp.ac.id,wawansetiabudi@uwp.ac.id
}

\begin{abstract}
Abstrak
Pengambilan keputusan sering kali dipertanyakan oleh setiap orang, bahkan menjadikan konfik secara internal didalam perusahaan dikarenakan data penyampaian dan penyajian berbeda-beda, penggunaan data serta pengolahan data ini sumber muaranya. Didalam pengambilan data yang diambil berdasarkan drawing sebagai refrensi yang menjadi permasalahan didalam pengambilan keputusan ini adalah bentuk penyajian data yang disajikan antara satu dengan yang lainnya berbeda, hal inilah yang berdampak pada pengambilan keputusan. Pengambilan keputusan pada intinya memastikan produk tersebut bisa digunakan apa tidak, pengambilan keputusan haruslah sesuai kesepakatan bersama, didasari pembuktian inspection yang dilakukan, serta dokumentasi atau hasil harus mudah dipahami dan di terapkan sehingga menghasilkan keputusan diterima atau ditolak. Untuk medukung sistem pengambilan keputusan maka dibutuhkan form API (Analysis Product Inspection) adalah template yang dioperasikan dengan MS Excel yang didalamnya terdapat 4 tabel yaitu tabel inspection, tabel measurement, tabel note reason dan tabel approval, yang diharapkan mampu mengambil keputusan $\mathrm{OK}$ atau tidak tidaknya status produk serta di bedakan berdasarkan gradiasi warna. Pada produk tutup kemasan minyak wangi di ukur menggunakan digimatic caliper $200 \mathrm{~mm}$, jumlah sample 5 pcs, average secara keseluruhan berwana hitam menandakan OK, tetapi dimensi yang keluar dari basic dimensions dengan nilai 16.60 dan 18.70 yang ditandai dengan gradiasi berwarna merah, hasil penyimpangan CPK adalah 0.24, 0.08, 0.50 dan 0.42 diantara nol dan satu menunjukan rata-rata proses terletak dalam batas spesifikasi dan hasil keputusan produk sesuai form API adalah OK. Tetapi yang perlu diperhatikan adalah sample part no 3 masih ditandai dengan gradiasi warna merah itu menunjukan cetakan moulding perlu dilakukan perbaikan
\end{abstract}

Kata Kunci : Inspection, Keputusan, Measurement, Ms Excel dan Produk

\section{PENDAHULUAN}

Proses manufactur pada saat ini meningkat tajam didalam pencapaian hasil penjualan produk, pencapaian produk yang sangat bagus tidak terlepas dari kemajuan teknologi meliputi permesinan, desain dan sumber daya manusia yang sangat handal didalam dunia globalisasi saat ini. Pada saat ini perusahaan automotif dan selular sudah mempercayai kemampuan permesinan-permesinan yang sudah memiliki tingkat ketlitian yang paling bagus yaitu sampai dengan nilai $0.001 \mathrm{~mm}$ dan memiliki pergerakan 5 axis. Proses pekerjaan molding atau cetakan diproses dengan menggunakan mesin CNC 
Keberhasilan produk juga tidak terlepas dari desain dan analisa produk, diera serba dengan era digital, desain yang ada saat ini banyak perusahaan menggunakan aplikasi CAD Solidwork yang mana di dalam penggunaannya solidwork mudah dipahami dan mampu menganalisa kemampuan product secara kekuatan, benturan antara komponen part dan biaya.

Teknologi informasi yang berhubungan dengan produk di pengaruhui oleh sistem pengukuran (linear, diameter dan angle) yang baik dan benar serta menggunakan alat yang memadai, untuk pemberian dimensi inspection produk maka di butuhkan gambar perencanaan sebagai dasar pengukuran. Didalam gambar 2 dimensi diberikan simbol inspection. Simbol inspection diaplikasikan terhadap dimensi-dimensi yang dianggap berhubungan dengan komponen yang lainnya, atau simbol inspection diaplikasikan terhadap fungsi produk.

Pemberian toleransi pada dimensi di lakukan dengan cara mengaplikasikan komponen part to part (assembly) dan hasilnya dapat diputuskan apakah menggunakan toleransi khusus atau toleransi standart. Didalam toleransi standart banyak variasi yang diterapkan misalnya general tolerance DIN 6930, General Tolerance 2768-mk dan lain sebagainya

Toleransi khusus perlu dicantumkan, misal dimensi dengan $20.0_{-0.30}^{+0.50}$ yang artinya dimensi batas atas adalah 20.50 dan dimensi dibawah adalah 19.70, apabila produk dengan dimensi hasil ukur menggunakan digimatic caliper menunjukan angka 20.40 maka bagian produk tersebut dinyatakan OK, dan apabila dimensi pengukuran menunjukan angka 20.60 (melebihi batas atas) bagian produk tersebut dinyatakan NG (Not Good).

Pembuatan produk pada umumnya menggunakan molding/cetakan, cetakan dapat menghasilkan produk masal penggunaannya, didalam proses produksi injecksi plastik bahan yang digunakan adalah plastik yang telah dipanaskan dan berubah bentuk menjadi cair, kemudian disemprotkan pada bagian cavity sehingga cairan plastik akan memenuhi ruangan atau rongga molding dengan temperatur $80^{\circ} \mathrm{C}$ serta pendinginan produk dengan menggunakan sistim kejut (dipaksa). Molding/cetakan apabila menggalami proses panas dengan temperatur yang tinggi akan mengalami perubahan bentuk. Sementara molding juga akan mengalami vibration saat dilakukan proses injeksi yaitu dengan buka tutup dari cetakan tersebut akan mempengaruhui komponen molding akan mengalami longgar atau aus dikarenakan gesekan, yang akan berpengaruh di produk.

Produk sebelum berubah status menjadi RFP (Release For Production) terlebih dahulu akan mendapatkan status report dengan kondisi aktualnya, report ini dikenal nama API Analysis Product Inspection yang menginformasikan bagianbagian atau point-point apa saja yang diberikan dimensi dan di lakukan inspection, serta mendapatkan hasil penilaian $\mathrm{OK}$ atau $\mathrm{NG}$ dan mengambil keputusan dengan status produk apakah Pass atau OK.

Untuk mencapai hasil kinerja API (Analysis product inspection) pada proses pengukuran maka dibutuhkan formula (rumus) yang tepat, untuk menghindari kesalahan didalam melakukan rata-rata setiap pointnya, yang megakibatkan dimensi OK menjadi NG dan dimensi NG menjadi OK.

\section{METODE}

\section{Pemodelan 3D Modeling Kemasan Minyak Wangi}




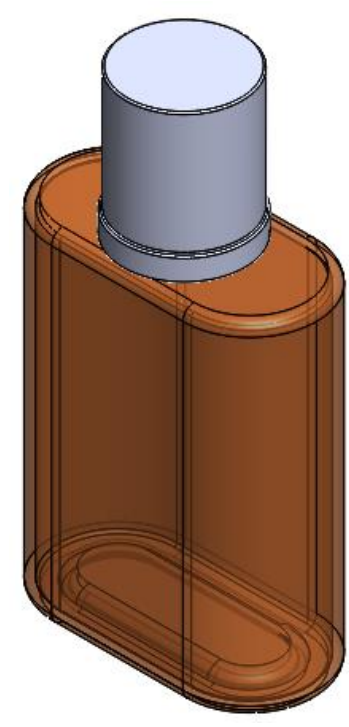

Gambar 1. (Kemasan Minyak Wangi)

Pemodelan ini menggunakan aplikasi SolidWork 2018 dengan mengambil contoh kemasan minyak wangi. Kemasan minyak wangi memiliki beberapa komponen yang mempunyai fungsi berkaitan dengan komponen yang lainnya. Dan berikut dibawah ini gambar 2. Potongan kemasan minyak wangi. Pada gambar potongan dapat dilihat 2 bagian posisi yang berbeda
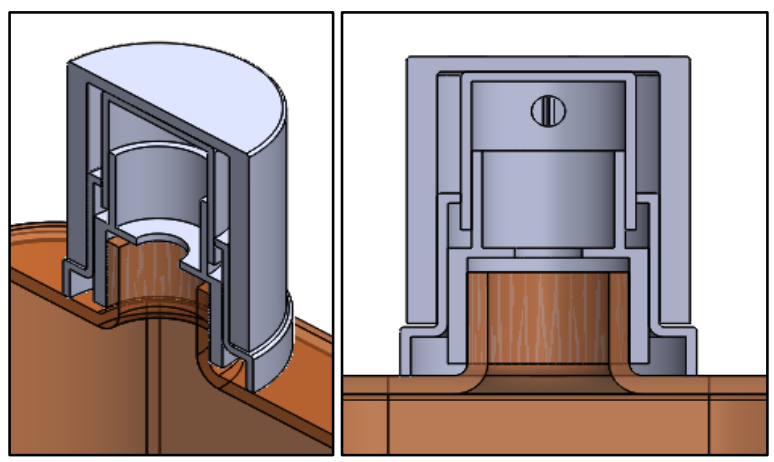

Gambar 2. (Potongan Produk Kemasan)

Pemodelan produk kemasan minyak wangi ini sesudah dilakukan proses assembly, dan dapat dilihat didalamnya terdapat beberapa komponen yang saling berimpitan satu dengan yang lainnya.

\section{Bill of Material}

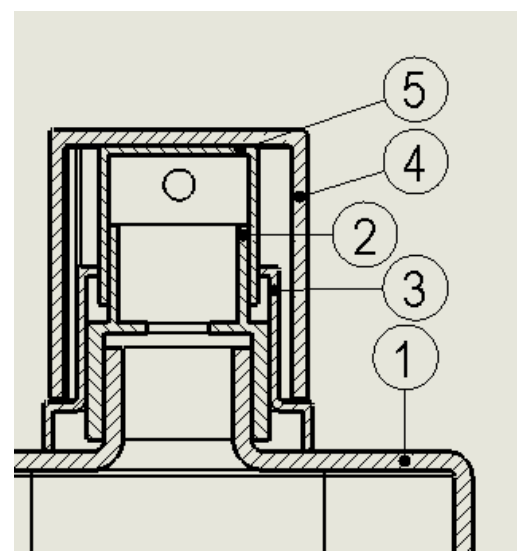

Gambar 3. (Bill of Material)

Pada bagian komponen part to part penamaan ini saya kondisikan dengan number bill of material

Tabel 1 Bill of Material

\begin{tabular}{lll}
\hline No & Name Part & Dimensi \\
\hline 1 & Bottle & $48.2 \times 24.2 \times 62$ \\
\hline 2 & Part-2 & $14.9 \times 5.0 \times 17.5$ \\
\hline 3 & Part-3 & $22.0 \times 14.9 \times 15.0$ \\
\hline 4 & Part-4 & $21.0 \times 18.5 \times 21.95$ \\
\hline 5 & Part-5 & $13.0 \times 11.40 \times 13.0$ \\
\hline
\end{tabular}

Dari data diatas dapat diketahui bahwa dengan dimensi paada tabel 1. Bill of Material dapat dipastikan komponen part ini membutuhkan toleransi khusus 


\section{Pemberian Dimensi pada Komponen Part yang Berhubungan dengan Komponen Part yang lainnya}

Pemodelan 2Drawing ini difokuskan pada inspection dimension tepatnya pada gambar part-4 (tutup kemasan minyak wangi). Sebelum membuat 2 Drawing tutup kemasan minyak wangi dan memberikan toleransi serta memberikan simbol inspection maka harus dilihat gap/celah atau benturan-benturan yang terjadi pada komponen part to part.

Berikut ini check dimensi awal untuk menentukan toleransi yang digunakan pada proses inspection

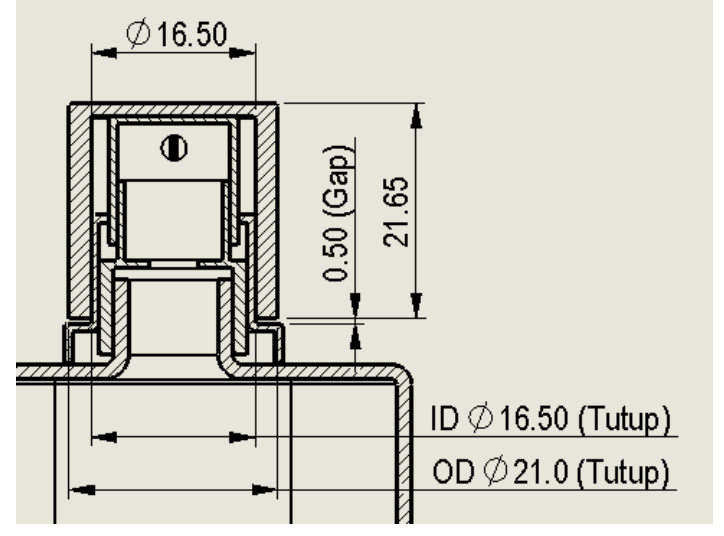

Gambar 4. (Pemberian Dimensi Terhadap Komponen Part yang Saling Benturan)

Berdasarkan gambar 4. Pemberian dimensi terhadap komponen part yang saling benturan dapat diambil kesimpulan bahwa komponen part-4 (tutup kemasan minyak wangi) berbenturan dengan part-3 khususnya pada bagian diameter dalam pada tutup menunjukan dimensi $\varnothing 16.50$ dan diameter luar menunjukan dimensi $\varnothing 21.0$ pada komponen part3 , dan ada gap/celah 0.50 antara tutup kemasan minyak wangi dengan part-3. Menentukan toleransi pada ketinggian tutup kemasan minyak wangi ada beberapa toleransi yang di izinkan 21.65 \pm 0.10 , $21.65 \pm 0.20,21.65 \pm 0.30$, atau $21.65_{-0.50}^{+0.30}$, dimana tutup kemasan minyak wangi benar-benar aman tidak akan menyentuh komponen part-3. Apabila tutup kemasan minyak wangi menyentuh komponen part-
3 dikhawatirkan tutup tidak dalam kondisi rapat sebab terganjal, dan apabila tutup menjauh dari part3 maka akan mempengaruhi tampilan produk menjadi jelek. Jadi yang pastinya toleransi yang digunakan $21.65_{-0.50}^{+0.30}$. Untuk diameter bagian dalam tutup kemasan minyak wangi toleransi lebih diperhatikan sebab kalau tutup kemasan minyak wangi toleransi semakin kecil maka tutup kemasan minyak wangi tidak bisa masuk dan apabila dipaksakan tutup kemasan minyak wangi akan pecah, dan apabila tutup kemasan minyak wangi toleransi semakin besar maka tutup kemasan minyak wangi tidak bisa mengunci (kebesaran/dol).

Maka yang ideal toleransi yang digunakan $\emptyset 16.50_{-0.15}^{+0.00}$, yang artinya ID tutup kemasan minyak wangi batas maksimalnya $\varnothing 16.50$ dan batas minimumnya atau batas bawahnya $\varnothing 16.35$

\section{Pemodelan 2Drawing Tutup Kemasan} Minyak Wangi

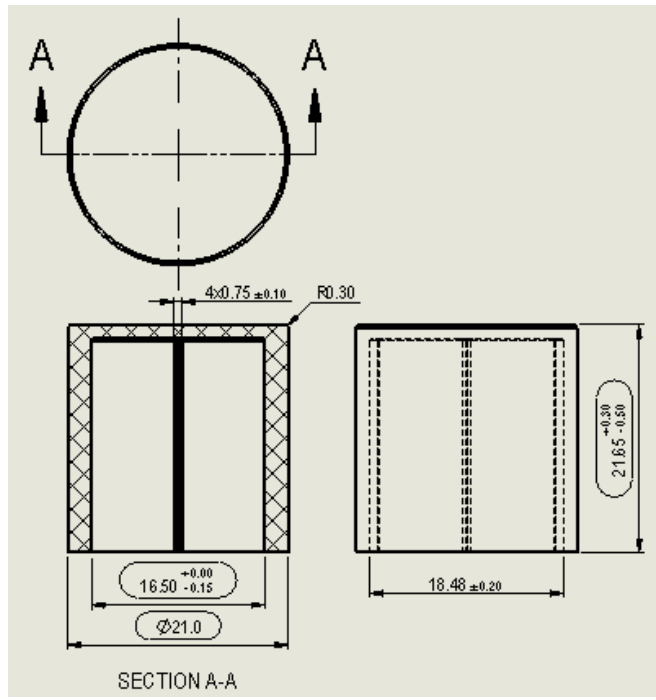

Gambar 5. (Pemodelan 2Drawing Tutup Kemasan Minyak Wangi)

Pada gambar 5, Pemodelan 2Drawing tutup kemasan minyak wangi terdapat simbol inspection yang artinya dimensi tersebut yang perlu di inspection.

Simbol inspection sudah diterapkan diberbagai perusahaan automotif dan smartphone, karena pada simbol ini sudah terdapat di CAD

Teknologi Informasi dan Komunikasi 


\section{API (Analysis Product Inspection)}

Analysis Product Inspection lebih tepatnya digunakan bagi pengguna pengolahan data dikarenakan memudahkan bagi user, Analysis Product Inspection karena hasilnya sudah dengan secara otomatis memberitahukan kepaada pengguna kalau hasil NG berwarna merah, dan hasil OK dengan warna hitam.

Analysis Product Inspection dibuat dengan menggunakan software Ms Excell hanya penggembangan formula yang bervariatif dan berikut ini formula pada API (Analysis Product Inspection) yang digunakan :

Formula hasil batas bawah

$=$ IF(D9<>"",VALUE(IF(ISERR(FIND("Ø",D 9) )=TRUE,LEFT(D9,IF(ISERR(FIND(" $\pm ", D 9))=T$


ND("Ø",D9)+2,IF(ISERR(FIND("士",D9))=TRUE,F IND("+",D9),FIND(" $\pm ", D 9))-3))$ )

VALUE(MID(D9,IF(ISERR(FIND("士",D9))=TRU E,FIND("-",D9),FIND(" $\pm ", D 9))+1,10)), "$ ")

Formula hasil batas atas $=\mathrm{IF}(\mathrm{D} 9<>"$ ",VALUE(IF(ISERR(FIND("Ø",D 9) )=TRUE,LEFT(D9,IF(ISERR(FIND(" $\pm ", D 9))=T$

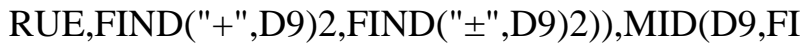
ND("Ø",D9)+2,IF(ISERR(FIND("士",D9))=TRUE,F IND("+",D9),FIND("士",D9))3)))+VALUE(MID(D9 ,IF(ISERR(FIND(" $\pm ", D 9))=T R U E, F I N D("+", D 9), F$ IND(" $\pm ", D 9))+1, \operatorname{IF}(\operatorname{ISERR}(\mathrm{FIND}(" \pm ", \mathrm{D} 9))=\mathrm{TRUE}$, FIND("/",D9)-1-FIND("+",D9),10))),"")

Formula Average

=IF(ISERR(AVERAGE(G9:K9((=TRUE,"”,AVER AGE(G9:K9))

Formula result $\mathrm{NG}$ atau $\mathrm{OK}$

$=\mathrm{IF}(\mathrm{M} 9<>$ " ",IF(OR(IF(M9<E9,1,0),IF(M9>F9 ,1,0))=FALSE,"OK","NG"),"")

\section{HASIL DAN PEMBAHASAN}

\section{Hasil Pengukuran}

Hasil pengukuran terhadap tutup Kemasan minyak wangi menggunakan digimatic caliper 200 mm, dan tidak membutuhkan peralatan lain karena sudah mewakili atau sangat layak digunakan

Tabel. 2 Hasil pengukuran tutup kemasan minyak

\begin{tabular}{cccccc}
\hline No & Ex-1 & Ex-2 & Ex-3 & Ex-4 & Ex-5 \\
\hline 1 & 21.10 & 21.20 & 21.20 & 21.10 & 21.10 \\
\hline 2 & 16.40 & 16.50 & 16.60 & 16.50 & 16.40 \\
\hline 3 & 21.60 & 21.60 & 21.50 & 21.60 & 21.60 \\
\hline 4 & 18.60 & 18.40 & 18.70 & 18.60 & 18.40 \\
\hline
\end{tabular}

Pada tabel 2 hasil pengukuran tutup kemasan minyak wangi dilakukan pengukuran menggunakan digimatic caliper $200 \mathrm{~mm}$, dan metode pengukuran dilakukan arah horisontal dan arah vertikal kemudian hasil dimensi dibagi menjadi 2 kemudian dimasukan ke dalam tabel

2. Hasil API (Analysis Product Inspection) per point Average

Tabel. 3 Hasil Pengukuran Tutup Kemasan Minyak Wangi secara Average

\begin{tabular}{|c|c|c|c|c|c|}
\hline $\begin{array}{c}\text { Basic } \\
\text { Dimensi }\end{array}$ & Ex-1 & Ex-2 & Ex-3 & Ex-4 & Ex-5 \\
\hline$\varnothing 21.0 \pm 0.20$ & 21.10 & 21.20 & 21.20 & 21.10 & 21.10 \\
\hline$\varnothing 16.50_{-0.15}^{+0.00}$ & 16.40 & 16.50 & 16.60 & 16.50 & 16.40 \\
\hline$\varnothing 21.65_{-0.50}^{+0.30}$ & 21.60 & 21.50 & 22.0 & 21.60 & 21.60 \\
\hline$\varnothing 18.48 \pm 0.20$ & 18.60 & 18.40 & 18.70 & 18.60 & 18.40 \\
\hline \multicolumn{6}{|l|}{ Average } \\
\hline$\varnothing 21.0$ & 21.160 & & & & \\
\hline$\varnothing 16.50_{-0.15}^{+0.00}$ & 16.480 & & & & \\
\hline$\emptyset 21.65_{-0.50}^{+0.30}$ & 21.200 & & & & \\
\hline$\varnothing 18.48 \pm 0.20$ & 18.500 & & & & \\
\hline
\end{tabular}

Pada tabel 3 hasil pengukuran tutup kemasan minyak wangi secara average pada point 2,3 dan 4 pada produk nomer 3 terdapat angka berwarna merah

Teknologi Informasi dan Komunikasi 
yaitu menunjukan pada bagian inspection tersebut yang menandakan dimensi inspection keluar dari batas basic dimension

\section{Hasil API (Analysis Product Inspection) per point CPK}

Dari hasil CPK (penyimpangan) terdapat ratarata dari hasil inspection per point bervariasi ini tergantung dengan hasil pengukuran diawal yang bervarian

Tabel. 4 Hasil Pengukuran Tutup Kemasan Minyak Wangi secara CPK (Penyimpangan)

\begin{tabular}{|c|c|c|c|c|c|}
\hline $\begin{array}{c}\text { Basic } \\
\text { Dimensi }\end{array}$ & Ex-1 & Ex-2 & Ex-3 & Ex-4 & Ex-5 \\
\hline$\varnothing 21.0 \pm 0.20$ & 21.10 & 21.20 & 21.20 & 21.10 & 21.10 \\
\hline$\varnothing 16.50_{-0.15}^{+0.00}$ & 16.40 & 16.50 & 16.60 & 16.50 & 16.40 \\
\hline$\varnothing 21.65_{-0.50}^{+0.30}$ & 21.20 & 21.20 & 22.0 & 21.20 & 21.20 \\
\hline$\varnothing 18.48 \pm 0.20$ & 18.60 & 18.40 & 18.70 & 18.60 & 18.40 \\
\hline \multicolumn{6}{|l|}{ CPK } \\
\hline$\varnothing 21.0$ & 0.24 & & & & \\
\hline$\varnothing 16.50_{-0.15}^{+0.00}$ & 0.08 & & & & \\
\hline$\varnothing 21.65_{-0.50}^{+0.30}$ & 0.50 & & & & \\
\hline$\varnothing 18.48 \pm 0.20$ & 0.42 & & & & \\
\hline
\end{tabular}

Pada tabel 4 hasil pengukuran tutup kemasan minyak wangi secara CPK (Penyimpangan) pada point 1, 2, 3 dan 4 terdapat nilai yang berwarna merah yang menandakan terdapat penyimpangan setiap produknya

\section{Hasil Keseluruhan API (Analysis Product Inspection)}

Tabel. 5 Hasil Keseluruhan Api (Analysis Product Inspection)

\begin{tabular}{cccccc}
\hline $\begin{array}{c}\text { Basic } \\
\text { Dimensi }\end{array}$ & Ex-1 & Ex-2 & Ex-3 & Ex-4 & Ex-5 \\
\hline$\varnothing 21.0 \pm 0.20$ & 21.10 & 21.20 & 21.20 & 21.10 & 21.10 \\
\hline$\varnothing 16.50_{-0.15}^{+0.00}$ & 16.40 & 16.50 & 16.60 & 16.50 & 16.40 \\
\hline
\end{tabular}

\begin{tabular}{|c|c|c|c|c|c|}
\hline $\begin{array}{c}\text { Basic } \\
\text { Dimensi }\end{array}$ & Ex-1 & Ex-2 & Ex-3 & Ex-4 & Ex-5 \\
\hline$\emptyset 21.65_{-0.50}^{+0.30}$ & 21.60 & 21.50 & 22.0 & 21.60 & 21.60 \\
\hline$\varnothing 18.48 \pm 0.20$ & 18.60 & 18.40 & 18.70 & 18.60 & 18.40 \\
\hline \multirow{2}{*}{ CPK } & \multicolumn{2}{|c|}{ Result } & & & \\
\hline & $\mathrm{OK}$ & $\mathrm{NG}$ & & & \\
\hline$\varnothing 21.0$ & \multicolumn{2}{|c|}{ OK } & & & \\
\hline$\varnothing 16.50_{-0.15}^{+0.00}$ & \multicolumn{2}{|c|}{ OK } & & & \\
\hline$\varnothing 21.65_{-0.50}^{+0.30}$ & \multicolumn{2}{|c|}{ OK } & & & \\
\hline$\varnothing 18.48 \pm 0.20$ & \multicolumn{2}{|c|}{ OK } & & & \\
\hline
\end{tabular}

Pada tabel 5 hasil keseluruhan api (Analysis Product Inspection) Hasil keputusan produk di pastikan OK secara keseluruhannya

\section{KESIMPULAN}

1. Hasil pengukuran menggunakan digimatic caliper $200 \mathrm{~mm}$

2. Pada tabel nomer 3 Hasil Pengukuran Tutup Kemasan Minyak Wangi Secara average, terdapat angka yang berwarna merah yang menandakan dimensi inspection keluar dari basic dimensions khususnya pada produk nomer 3. Berarti produk tersebut bermasalah di dalam pembuatan molding/cetakan, tetapi secara keseluruhan bisa digunakan

3. Pada tabel 4 hasil pengukuran tutup kemasan minyak wangi secara CPK (Penyimpangan) mendapatkan hasil $0.24,0.08,0.50$ dan 0.42 diantara nol dan satu menandakan rata-rata proses terletak dalam batas spesifikasi tetapi bagian variasi terletak diluas spesifikasi

4. Pada tabel 4 hasil keseluruhan API (Analysis Product Inspection) Hasil keputusan produk dipastikan OK per pointnya dan pada bagian warna merah dilakukan improvement terhadap molding/cetakan, atau melakukan perubahan basic dimension

\footnotetext{
Teknologi Informasi dan Komunikasi
} 


\section{UCAPAN TERIMA KASIH}

Ucapan terima kasih juga kami sampaikan kepada Bapak Rektor, ketua LPPM dan Dekan Teknik Universitas Wijaya Putra yang banyak memberikan dorongan dan masukan sekaligus melakukan monitoring pelaksanaan kegiatan ini.

\section{REFERENSI}

Andes Rifano, Pengenalan Standart Gambar Teknik dan Angka Toleransi Menurut Standart ISO

Endi Sutikno, 2016, Modul Tugas Besar Menggambar Teknik, Universitas Brawijaya

Purnami, 2017, Modul Tugas Besar Menggambar Teknik, Universitas Brawijaya

Rahmat Fauzi, Yulia, 2018, Menggambar Teknik, Diktat, Universitas Putera Batam

Ryan Fitria, 2011, Modul TKR, Menginterprestasikan Gambar Teknik, Yogyakarta 